\title{
DEFINITION OF LOCAL SELF-GOVERNMENT IN THE CONTEXT OF LOCAL DEMOCRACY DEVELOPMENT IN UKRAINE
}

\section{Naumkina S. M.}

\section{INTRODUCTION}

Democracy is the system that extends to large pluralistic societies with an ever-changing system of internal and external interactions in the first quarter of the XXI century. It requires a radical reorganization of the political system and institutions of power and governance, and therefore the discovery of new essential characteristics of democracy associated with specific forms and the degree of participation of the population in the exercise of power at all levels.

Now the main enemies of democracy aren't a monarchy or an oligarchy, as it was in last. Today the main theme, which associated with democracy, is not the justification of the idea of democracy through ethical, theological, philosophical or sound arguments, but concern for its fragility and the searching for ways to strengthen it.

Obviously, the task of preserving and consolidating democracy can be successfully solved of its nature. Therefore, attention should focus not on the diversity of definitions of this concept, but on its quintessence, the dominant purpose. We can apply the approach to understanding democracy, which is the most widespread in modern political science: «develop some set of rules and principles (the constitution), which will determine the order of decision-making in a particular association». Moreover, this constitution should be in accordance with one elementary principle - all members of the association should be treated as if they were all equally competent to participate in the decision-making process regarding the policy that the association intends to implement.

\section{Institutional basis of the nature of democracy}

A well-known political scientist R. Dahl, who introduced the term «polyarchy» into a new political lexis, substantiated the main differences between the modern nature of democracy and the main procedural criteria that form and act as the institutional foundations of the nature of 
democracy. There are five criteria: 1) effective participation; 2) equal voting; 3) understanding based on informativity (awareness); 4) control over the agenda; 5) Inclusion in society ${ }^{1}$.

In these criteria R. Dahl saw the real opportunities, which was provided by democracy. Effective participation should be understood as the active position of any member of the association, which should have equal and effective opportunities to present their views on the essence of this policy to other members of the association, prior to the adoption of the association policy all members of this society. Equal voting involves not only the fact that all members of the association had had the same opportunities for voting before the decision, and that votes of all members of the association are equally valid. The understanding based on awareness consists in the fact that each member of the association should receive equal and real opportunities for familiarizing with political alternatives and their likely consequences. The control of the agenda assumes that members of the association have exceptional opportunities to decide on which issues and in which order they are subject to discussion ${ }^{2}$.

Thus, the democratic procedures aren't been exhausted by the three preceding criteria.

Association policy is always open to change, if it's required by its members. Finally, the criterion of inclusion in the life of society is realized in the process of participation in the democratic process of adolescents. Such participation implies that all members of the association should have full civil rights, as provided by the first four criteria, and they have reached the age of majority.

In the conditions significant importance of democracy acquires the legal status of a particular member of the association. T. Parsons distinguished three phases of the development of citizenship, in which the establishment of legal or civilian boundaries of the behavior of the member of the association.

In the first phase, it determines newly the adjacent relations between the societal community (it's characterized by a complex network of interpersonal relationships and in which each member of society at the same time is a member of a number of associations created

1 Даль Р. О демократии. Москва: Аспект Пресс, 2000. С. 123.

2 Див. детал.: Даль Р. О демократии. Москва: Аспект Пресс, 2000. С. 123-167 
on various grounds - professional, national, religious, ethnic, territorial, etc.) and government or state. The manifestation of these new boundaries was the definition of «rights» of a citizen, which protection turned into the very first duty of the state. The second phase of the development of citizenship is connected with the participation of citizens in public affairs. It's institutionalized positive rights to participate in the election of ruling leaders and enshrined in electoral law in this stage. The third component of citizenship is the social care of the welfare of citizens, considered as «a part of public responsibility». Consequently, if civil rights and electoral law make it possible to independently realize their civil status, then the social component is connected with the creation of real conditions for the better use of these rights. It means an attempt to provide the general population with an adequate living wage, access to health care and education ${ }^{3}$.

The spread of education to the general population and raising its level are directly and closely related to the development of the civil complex in the members

of the association. The attention of T. Parsons idea is that the development of modern institutions of citizenship had made a significant contribution to the concept of nationality as the basis of solidarity socialist society.

Strong foundations of solidarity existed where religious, ethnic and territorial factors merged in the concepts of nationality in the past. there can be many religious, ethnic and territorial foundations, as they provide the general principle of citizenship in modern societies ${ }^{4}$.

In this place the role of the collective is institutionalizated and increased as the most important element in the structure of the social system, which functions and manifests itself as a «voluntary selforganization» (or association) in the conditions of modern society. The basis for such a self-organization is the social community, in the form of a corporate association of citizens who has a relatively complete agreement on its normative system and authority of leaders ${ }^{5}$.

3 Парсонс Т. О структуре соичального действия. Москва: Академический проект, 2000. С. 34.

${ }^{4}$ Там же. С. 161.

${ }^{5}$ Там же. O структуре сочиального действия. Москва: Академический проект, 2000. C. 168. 
Considering the process of formation and development of such associations, T. Parsons highlights their main characteristics, among them the main is its certain egalitarianism (equality), which most clearly manifests itself in the three phases of citizenship. The second feature of the associations is their voluntary nature. And although, according to T. Parsons, this principle cannot be applied with all harshness in situations of obedience to normative order or collective decisions containing the mandatory element, it is almost literally fulfilled when making decisions on membership in an association. The third characteristic feature of associations is the importance of procedural institutions as a special self-organization of human groups. And although procedural moments of particular importance are in the legal system, they also enrich the decision-making processes in any association both at the level of the representative and at the level of internal relations ${ }^{6}$.

An analysis of these criteria shows that they are equally important and applicable to all levels of human associations: both at the state level and at the level of local societies created on the basis of professional, cultural, national, territorial and other grounds. However, these criteria of the democratic process play the most important role in the establishment and functioning of the institution of local self-government.

The first, they correspond, agree and being in synergy with the everyday laws of human life and the processes of formation and existence of territorial communities, permeate and determine the dynamics of their functioning, «fasten» members of the territorial association in a single the whole, assuming and realizing the very possibility of its creation.

Secondly, on their basis, there isn't simply association of individuals, which is fixed by ties of a passive nature and based on the principle of common life; community characterized as «active», which has a «person», who find their refinement and consolidation with the goals and objectives that need to be achieved at the tactical and strategic levels of the existence of the association.

Third, these criteria aren't directed only to the formation of a territorial association as a single community of individuals living in the same territory, but also have a powerful «reciprocal effect» - they promote and stimulate the development of each particular individual

6 Див. детал.: Парсонс Т. O структуре социального действия. Москва: Академический проект, 2000. С. 165-176. 
member of the territorial community, forming it as «inhabitant» in the positive sense of the word, with all the plurality inherent in it local interests ${ }^{7}$.

The «local factor» is rather important in analyzing the relation and interaction of democracy, a democratic state (political) regime and civil society, which was made by the American scientist D. Held. He distinguished the next models of democracy: a) classical; b) direct; c) protective (defense democracy); d) developmental democracy ${ }^{8}$.

The main features of classical democracy are short terms of election to power posts; maintenance at the expense of the society of the administrative apparatus; availability of different ways to exercise electoral law; presence of a higher collegial body of sovereign power of the people. The subject of power regulation is all spheres of public life and citizens are involved in the exercise of legislative and judicial functions.

D. Held considered the main features of direct democracy, first of all: all public affairs are regulated by a specially organized administrative structure of the pyramid type (from top to bottom); the management apparatus receives for its activities the same remuneration as workers in other sectors; rotation in the control apparatus is carried out by means of the withdrawal of candidates by voters; the presence of a powerful structure of force law enforcement support.

The model of «protective democracy» is based on compulsory availability of competing power centers. Sovereignty necessarily belongs to the people, but it delegates a significant part of its power to legitimately elected statesmen. Power in the state is divided into executive, legislative and judicial. The institutional basis of stability is the conduct of regular elections in society, on which decisions are made on the basis of the majority of votes. The rule of the constitutional principles, which unambiguously establish a circle of fundamental rights and freedoms of human and citizen, and it can`t be limited to any political power.

D. Held formulated the basic principle of the functioning of the fourth model of the «developmental democracy»: «Citizen participation in political life is conditioned not only by the need to protect individual

7 Прієшкіна О. В. Місиеве самоврядування в Україні: правове регулювання безпосередньої демократії. Київ: Кондор, 2004. С. 24-26.

${ }^{8}$ Held D. Models of Democracy. Stanford: Stanford U.P., 1987. P. 34. 
interests, but also the development of a general awareness of civic unity» ${ }^{9}$. The defining features of this model of democracy are the constitution establishes a clear balance between collective and individual rights; the expansion of the management function carried out by the «bureaucrats», and the functions of lawmaking are exercised by the elected body; development of the system of local self-government; the influence of citizens on the processes of public administration is carried out both through the exercise of electoral law, and by the method of individual participation ${ }^{10}$.

The conclusion is based on the results of the analysis of democratic models. The «local» factor has a significant significance and is manifested in all models of democracy, but most clearly, visibly and reasonably. It functions in the model of the «democracy of development». There is an objective need for an analysis of local self-government and its correlation with democracy in different hypostases of its manifestation.

Among the different forms of democracy, national and foreign researchers identify as the supreme so-called "participatory democracy», when citizens participate in the process of making managerial decisions, including at the local level. At the same time, participatory democracy has both its advantages and the disadvantages (challenges) that need to be taken into account in practical activities at the local level.

At the same time, researchers identify certain threats (or certain difficulties) that may arise in the process of involving citizens in solving local issues ${ }^{11}$.

The first threat is the openness of the authorities' actions and the inability to hide the existing shortcomings in municipal management. A certain preventive measure against this threat is the wider involvement of citizens in solving local issues (not only informing but also seeking to find the optimal solution). However, the final decision is still taken by the local authorities responsible for the decisions made.

The second threat may be the populism of power. It would give something to somebody to gain some benefits in the future. Citizens don `t always agree on this, especially if the benefits are promising in too far

${ }^{9}$ Held D. Models of Democracy. Stanford: Stanford U.P., 1987. P. 34.

${ }^{10}$ Held D. Models of Democracy. Stanford: Stanford U.P., 1987. P. 35.

11 Посібник з питань партисипативної демократії (демократії участі) на місиевому рівні / В. В. Толкованов, А. К. Гук, В. М. Олуйко, В. Я. Прошко. Київ: Крамар, 2011. С. 36-45. 
away or if the population doesn't have a great deal of trust in the authorities.

The third threat is defined as the «blurring of responsibility», and it is a certain contrast to the benefits of the «division of responsibility», which was discussed above.

The fourth threat is defined as «time expenditures», because communication with the community takes a lot of time from officials of local self-government bodies. As a rule, communication with citizens is a mandatory element in job descriptions of employees in European countries, and such communication takes a significant part of their working time in certain categories of officials and politicians.

The creation of a legal basis for a democratic state in a rather short historical time in Ukraine, as in most post-Soviet countries, makes for the parallel development of a large number of normative legal acts, first of all, laws that would condition the formation, development and functioning of major democratic institutions. It belongs also to local selfgovernment and becomes a social environment of democracy, where the processes of formation and institutionalization of certain organizations take place the authorities, as well as certain forms of self-organization of citizens.

\section{The condition of development of local democracy in Ukraine (based on the analysis of the constitutional definition of local self-government)}

Finding out the place and role of local democracy in Ukraine can be done on the basis of an analysis of the constitutional definition of local self-government. According to Art. 140 of the Constitution of Ukraine, «local self-government is the right of a territorial community - residents of a village or voluntary association in a rural community of residents of several villages, settlements, cities - to independently solve issues of local significance within the constitution and laws of Ukrain» ${ }^{12}$. In this context, it is necessary to clearly identify the circle of subjects of local self-government and their priority. According to the same article 140 of the Constitution of Ukraine, the primary subject of local self-government

12 Про місцеве самоврядування в Україні: Закон України [зі змін. та допов., від 17.07.2015 № 650 - VIII]. URL: http://http://www.vinrada.gov.ua/zakon_pro_misceve_ samovryaduvannya_v_ukraini.htm(дата звернення 23.04.2019) 
is a territorial community - a set of residents of a certain territory, and not only citizens of the state, living in this territory. At the level of local selfgovernment within the territory of a territorial community, actors live in a certain territory and operate primarily as its residents. Under the territorial community (local community) should be understood as a set of individuals. They are permanently residing in a specified territory. This communities are linked to each other by territorial-personal ties that are systemic in nature. All other subjects of local self-government are formed by the territorial community with the help of forms of direct (direct) and indirect (indirect) democracy and are characterized by its secondary, derivative character.

The traditional approach to grading of forms of democracy is widely used, and it depends on the form of expression of the will of the people. The Constitution of Ukraine proclaims a comprehensive and complete democracy, as well as forms of democracy - direct and indirect (representative). The Constitution of Ukraine is established the Institute of Political Representation.

It was accepted to consider the representative form of government as leading in relation to the direct in the Soviet political and legal literature. This idea was enshrined in the Constitution of Ukraine in 1996, where a number of provisions show a higher level of its legal regulation, and it establishes its types, subjects, their powers, organizational and legal forms of activity, etc. Therefore, we cannot fully agree with M.I. Stavniichuk, who argues that today it is possible to state the fundamental changes in the priorities of the realization of democracy in the open spaces of Ukraine in favor of the immediate exercise by the people of the state power which belongs to him. It contributes to real engagement of citizens, to the management of state affairs and creates conditions for reducing the alienation of citizens from power, which always exists in any society, even the most democratic ${ }^{13}$.

It is believed that this tendency is correct in terms of its semantic load, logical construction. This is correctly defined, according to the strategic directions of the development of a democratic state, but unfortunately, it is not always fully «operational» in practice.

${ }^{13}$ Реформування місцевого самоврядування - запорука розвитку територіальної громади. URL: http://www.rv.gov.ua/sitenew/main/ua/publication/content/20903.htm (дата звернення 26.04.2019) 
This opinion is shared by the representatives of the Coordination Council on the reform of the Institute of Local Self-Government in Ukraine, which indicate that both forms of exercising power by the people (bodies of state power and bodies of local self-government) are equal and the list of forms of people the expression of will through elections, referendum and other forms of direct democracy is inexhaustible and can be specified by the norms of the national and local legal acts $^{14}$.

During the years of Ukraine's independence, attention to the forms of local democracy has been paid to the legal regulation of local elections, due to the

increased interest from them by the political forces of Ukraine and the international community. However, the legal regulation of this form of local democracy can not be considered stable and perfect. After all, several election laws had been passed in Ukraine before the electoral process began, with a radical change in key positions, in particular, on the way in which representative bodies they were formed. At the same time, certain provisions of the Law of Ukraine "On the bodies of selforganization of the population» contradict the norms of the current legislation of Ukraine. In practice, these regulatory gaps, the vagueness and ambiguity of the wording impede the creation and activities of the bodies of self-organization of the population and don't allow members of territorial communities jointly and under their responsibility to solve problems at the place of residence.

Over the past years, the Cabinet of Ministers of Ukraine has adopted several acts related to the development of local democracy. Thus, it was approved the procedure for facilitating the conduct of a public examination of the activities of executive bodies, which granted civil society institutions, bodies of self-organization of the population the right to conduct a public examination of the activities of executive authorities, in particular local executive authorities. The Cabinet of Ministers of Ukraine has recommended to local self-government bodies to disseminate the mechanism of conducting public examination on them. As practice shows, only a few local self-government bodies have taken advantage of

${ }^{14}$ Див.: Місиеве самоврядування в Украӥні: сучасний стан та основні напрями модернізації: наук. доп. / [редкол.: Ю. В. Ковбасюк, К. О. Ващенко, В. В. Толкованов та ін.]; за заг. ред. д-ра наук з держ. упр., проф. Ю. В. Ковбасюка. Київ: НАДУ, 2014. $128 \mathrm{c}$. 
this recommendation, which has the effect that civil society institutions today have no real opportunity to conduct a public examination of the activities of local self-government bodies ${ }^{15}$.

Consequently, we can conclude that the current legislation of Ukraine is imperfect and impedes its development in the issues of local democracy. And the current approach eliminates the initiative of the inhabitants and brings it to naught,

when the possibility of citizens' participation in the management of local affairs depends primarily on the goodwill of a government body or official. This leads to a decrease in public confidence in the government, promotes the strengthening of such negative phenomena as absenteeism and the alienation of members of territorial communities from attempts to independently solve topical problems of local development. The lack of effective mechanisms for solving problems leads in some cases to aggravation of social conflicts and the spread of such radical forms of public expression of will, such as pickets, rallies, roadblocks and other actions of civil protest.

The level of development of local democracy in Ukraine is a constant subject of monitoring of the European community and the European Committee of Local and Regional Authorities of Europe, which reveals a number of factors limiting the content of local self-government in Ukraine: the tendency to centralize the powers of national agencies; lack of a stable economic base at the local level; the weakness of the financial system of local and regional authorities; the lack of clear division of powers and administrative activity between central government agencies and local and regional authorities. It may result in intersection or duplication in the exercise of authority.

These trends contradict the provisions of the Law «About Local SelfGovernment in Ukraine», according to which state control shouldn't lead to interference with the exercise of local self-government bodies. Although the purpose of this limitation relates to a particular supervisory issue, it can be used more widely to restrain efforts by the central government to influence the allocation and exercise of powers to the detriment of local authorities and their right to self-government.

15 Про затвердження Порядку сприяння проведенню громадської експертизи діяльності органів виконавчої влади: Постанова Кабінету Міністрів України від 05.11.2008 3а №976 [зі змін. ma доповн., від 08.04.2015 № 234]. URL: http://zakon4.rada.gov.ua/laws/show/976-2008-п(дата звернення 20.05.2019) 
The development of local democracy and political representation on the ground is under the influence of the development of civil society in modern countries of the world and in Ukraine. Such interdependence of democracy and civil society can be carried out in accordance with one of four models: classical, direct, protective, developmental. The local factor is essential and manifested in all models of democracy, but most clearly, visibly and reasonably, it operates under the conditions of the latter model, which involves the participation of citizens in political life, which is conditioned not only by the need to protect individual interests, but also the development of a general awareness of civic unity. It is considered as a prerequisite for the introduction of high-quality political representation on the ground.

As to the theoretical measurement of the content of the local selfgovernment institute, it is worth analyzing the issues of local selfgovernment as a system with organized unity of elements that has the properties of self-regulation and self-reproduction. Every system is an element of a more complex and larger system, which with respect to this system is called macrosystem.

There is a danger of considering the system of local self-government as a phenomenon without consider the laws, principles of functioning of this macrosystem and their relationship with local self-government. It is inherently intelligently and purposefully evolving, as it happened and is quite satisfactory in essence, an element of social structure and social relations. Unfortunately, this is exactly what the evolution of the system of local self-government and its present state are being considered in many works of national researchers.

Self-government arises simultaneously with society and develops along with it. The need for it arises in connection with the need for joint activities, collective efforts, and therefore - the implementation of general management functions, without which society cannot function.

It is worth agreeing with the position that «... the prototype of today (and future) self-government was elemental self-regulation, manifestations of which appear at the earliest stages of sociogenesis, that developed under laws they were different from biological ones. The essence of such self-regulation, which was a prerequisite for the survival of a person in conditions of strict biological competition and adverse environmental conditions. 
It was to ensure the vital functions of the original prototype communities, the balance between the collective and individual interests» ${ }^{16}$. It is covered the distinction between self-government (which covers all manifestations of both spontaneous) and conscious selfregulation of social life and management (which is manifestation of only conscious self-regulation, which is carried out in order to achieve the corresponding goal).

There is a cognitive paradox of «spontaneous management» because the term management involves conscious action to achieve the goals. «Spontaneity» and "management" is categories that exclude each other. However, neither spontaneity nor consciousness is found in its pure form. It is more correct to speak about a certain correlation of spontaneity and awareness in management the assessment of the dominant components of the first or second component may be determined by the position of the researcher, the level of development of science and the so-called effect of authorization.

From the point of view the notion of self-organization and selfregulation is wider than the concept of social governance of the dialectical relationship between conscious and spontaneous in the regulation of social processes, because not all kinds of manifestations of social self-regulation can be implicitly attributed to management. Consequently, the management objectively cannot cover all aspects of public life, many of its aspects are regulated by spontaneous (objective) self-regulation, which cannot be determined as a management in the paradigm of modern science.

In its turn, spontaneous self-regulation may include both constructive, creative, and certain destructive, destructive potential, which is aimed at changing the outdated, regressive existing system of self-organization of society. It is impossible to define how to manage such forms of social self-regulation as wars, revolutions, revolts, and other social power conflicts, as a result of which there is a dramatic flowering of existing differences in society.

Thus, self-government is a category that is used to characterize any manifestation of self-regulation, self-organization, self-control. That is

16 Див.: Децентралізачія публічної влади: досвід європейських крайн та перспективи України / [Бориславська О. М., Заверуха І. Б., Школик А. М. та ін.]; Центр політико-правових реформ. Київ: Изд-во О. М. Москаленко, 2012. 212 с. 
objectively inherent in any society, community, group as a holistic dynamic social system in which decision-making processes take place.

Society is a universal self-governing social system. It consists of a hierarchy of subsystems of a different nature capable of selfdevelopment. Self-government is a form of self-regulation, selforganization not only of society but also of other social communities of people (national, confessional, professional, territorial communities and other groups) in the process of which ensures the preservation of their integrity, identity, qualitative specifics, their self-reproduction and selfdevelopment.

Consequently, the notion of self-governance can be affected far from unambiguous phenomena and processes of social life. It is often interpreted in broad and narrow terms. In the broad sense, the comprehensive form of self-organization of society can be considered primarily a state that arose as a product of social development and to no extent is a force imposed on society from the outside. It is in this sense that the notion of state sovereignty is interpreted, which indicates the source and at the same time the object of power.

However, the term «self-government» is used in the narrow sense as a synonym for local self-government in modern foreign and national literature. That in a relatively autonomous management of public affairs is carried out by the population of the corresponding administrativeterritorial unit directly or through the bodies they have formed, and not through central authorities. In this sense, this concept was formed relatively recently, although ideas and practices of local self-government arose in ancient times.

The focus is mainly on the characterization of «statics» of local selfgovernment, and not its dynamics in such a narrow sense. At the same time, such an approach to the analysis of the phenomenon of local selfgovernment is objectively inadequate, because it does not reveal the very technology of its functioning, mechanisms of interaction of local selfgovernment with other elements of social structure, problems of duplicate contours, positive and negative feedback in the macrosystem society, because the rules of law cannot cover all aspects of local selfgovernment, which is much more complex and diverse phenomenon than it can be concluded, based on formal analysis.

That is why the characteristics of local self-government only through the rules of law, which determine the order of its implementation. It does 
not reveal in full the entire essence of this phenomenon of social life, which is hidden under the relevant normative wording. In this way, the internal conflict of self-government and governance, which can be explained although reflecting different aspects of one and the same phenomenon social being, and conditioned by the aspirations of any hierarchical systems to expand the influence and expansion of sovereignty.

The problem lies in a certain duality of the system of local selfgovernment, whose authority does not start either in this system itself or in the territorial community controlled by this system. Receiving authority on the basis of legal norms that have their source outside the specified system, local self-government does not have sovereignty, and therefore cannot be considered as a closed self-sufficient system. The inevitable conflict between the interests of the state and the individual is refracted in the conflict, the culprits of which are the territorial community and the system of local self-government. It is the existence of a system of local self-government that is determined by a system of compromises, a shaky balance of interests and not always a perfect system of checks and balances. Own interests of the system of local selfgovernment, as a kind of corporate structure, are in difficult relationships with the interests of the territorial community, which, formally being an element of local self-government, is not a hierarchical structure and has neither sovereignty nor authority. At the same time, the state authorities are inclined to consider the system of local self-government as a kind of vassal and every effort to limit the autonomy of local self-government, creating duplicate structures of the executive verticals. All this is characteristic, rather, for a complex dynamic system, which is in a state of unstable equilibrium, than for a static, stable and internally stable.

\section{CONCLUSIONS}

The general level of governance does not allow it today to qualify for international recognition as a state that meets modern democratic standards in Ukraine, which doesn't allow to consider the system of local self-government. It is a subsystem of the general political macrosystem, as effective and conforming to the specified standards.

The main markers of a developed civil society are the level of corruption, the level of citizens' satisfaction with the quality of their lives, the level of social protection, life expectancy. They point to the imperfection of the existing system of organization of society, and the 
imperfection of the system of local self-government. Therefore, the existing system of local self-government is rightly regarded as a dynamic system generated by political and social conflicts of interest that is in a state of permanent crisis and far enough from a stable state and functional perfection.

The power field of the existence of local self-government is built between the state and the community, creating the corresponding vectors of tension and a certain theoretical and legal conflict. In cases where local self-government is the successor to historically more or less independent self-government bodies of local communities, one can talk about the state as an integral unifier of interests in relation to autonomous entities. In the same cases, when local self-government arose as an attempt by the state to get rid of unpleasant and uninteresting functions for it, one can speak of «leaking» powers from top to bottom.

At the formal and legal identity of both these forms of local selfgovernment, their origin imposes an imprint on their essence and on the relationship between these local governments and society. The range is gone from the almost complete independence of territorial communities from state authority (Switzerland) to the almost complete subordination of local self-government to state authorities, to the simulativedemonstration functions performed by this institution in a society with simulation democracy (Belarus).

Understanding local self-government involves a more detailed and detailed study of this phenomenon in the plane of its practical manifestations. It can be as a multi-faceted phenomenon, as a system is characterized by processes that change the system itself over time.

Effective democracy and good governance are essential elements for conflict prevention, maintaining stability, promoting economic and social development, and hence for sustainable community development at all levels. The basic idea is that local authorities are closest to citizens and provides them with basic services, and at this level, citizens can quickly feel their involvement in the adoption and implementation of the most important decisions.

Taking into account the trends of the development of local democracy in the modern world is important for Ukraine and should be used in the process of modernization of the system of local selfgovernment. 


\section{SUMMARY}

The article is devoted to issues by the level of a modern democracy, which extends to large pluralistic societies with a constantly changing system of internal and external interactions. It requires a radical reorganization of the political system and institutions of power and governance, and hence the discovery of new essential characteristics of democracy associated with concrete forms and the degree of participation of the population in the exercise of power at all its levels.

The conclusions are based on the results of the analysis of democratic models. We can conclude that the «local» factor has a significant significance and it is manifested in all models of democracy, but most clearly, visibly and reasonably. It functions in the model of the «democracy of development». There is an objective need for an analysis of local self-government and its correlation with democracy in different hypostases of its manifestation.

Self-government arises simultaneously with society and develops along with it. The need arises in connection with the need for joint activities, collective efforts, and the implementation of general management functions, it cannot function without society. The trends of the development of local democracy in the modern world have the great importance for Ukraine. It should be used in the process of modernization of the system of local self-government.

\section{REFERENCES}

1. Даль Р. О демократии. Москва: Аспект Пресс, 2000. 208 с.

2. Парсонс Т. О структуре социального действия. Москва: Академический проект, 2000. 880 с.

3. Прієшкіна О. В. Місцеве самоврядування в Україні: правове регулювання безпосередньої демократії. Київ: Кондор, 2004. 336 с. $134 \mathrm{p}$.

4. Held D. Models of Democracy. Stanford: Stanford U.P., 1987.

5. Посібник з питань партисипативної демократії (демократії участі) на місцевому рівні / В. В. Толкованов, А. К. Гук, В. М. Олуйко, В. Я. Прошко. Київ: Крамар, 2011. 199 с.

6. Про місцеве самоврядування в Україні: Закон України [зі змін. та допов., від 17.07.2015 № 650 - VIII]. URL: http://www.vinrada.gov.ua/zakon_pro_misceve_samovryaduvannya_v_u kraini.htm (дата звернення 23.04.2019). 
7. Реформування місцевого самоврядування - запорука розвитку територіальної громади. URL: http://www.rv.gov.ua/ sitenew/main/ua/publication/content/20903.htm

8. Місцеве самоврядування в Україні: сучасний стан та основні напрями модернізації : наук. доп. / [редкол.: Ю.В.Ковбасюк, К. О. Ващенко, В. В. Толкованов та ін.]; за заг. ред. д-ра наук з держ. упр., проф. Ю. В. Ковбасюка. Київ: НАДУ, 2014. 128 с.

9. Про затвердження Порядку сприяння проведенню громадської експертизи діяльності органів виконавчої влади: Постанова Кабінету Міністрів України від 05.11.2008 за № 976 [зі змін. та доповн., від 08.04.2015 № 234]. URL: http://zakon4.rada.gov.ua/ laws/show/976-2008-п (дата звернення 20.05.2019)

10. Децентралізація публічної влади: досвід європейських країн та перспективи України / [Бориславська О. М., Заверуха I. Б., Школик А. М. та ін.]; Центр політико-правових реформ. Київ: Издво О. М. Москаленко, 2012. 212 с.

\section{Information about the author: Naumkina S. M.}

Doctor of Law, Professor at the Department of Political Science and Law, State institution «Southern National Pedagogical University named after K. D. Ushinsky»» 26, Starofrankivska str., Odesa, 65000, Ukraine 